\title{
GEOARCHAEOSITES FOR GEOTOURISM: A SPATIAL ANALYSIS FOR RARH BENGAL IN INDIA
}

\author{
Premangshu CHAKRABARTY* \\ Visva-Bharati University, Faculty of Geography, Department of Geography, \\ Santiniketan, Bolpur, West Bengal, India, e-mail: drpremangshuindia@gmail.com \\ Rahul MANDAL \\ Visva-Bharati University, Department of Geography, \\ Santiniketan, Bolpur, West Bengal, India, e-mail: rahulskbu1992@gmail.com
}

\begin{abstract}
Citation: Chakrabarty, P., \& Mandal, R. (2019). GEOARCHAEOSITES FOR GEOTOURISM: A SPATIAL ANALYSIS FOR RARH BENGAL IN INDIA. GeoJournal of Tourism and Geosites, 25(2), 543-554. https://doi.org/10.30892/gtg.25221-379
\end{abstract}

\begin{abstract}
Rarh Bengal in India is a well known lateritic landscape endowed with a number of geoarchaeological sites. Research gaps have been identified in the systematic mapping and location analysis on the nature of distributional pattern of such geoarchaeosites from the perspective of planning a number of geotourism circuits. With application of nearest neighbour analysis and GIS based digital cartography, this paper is an attempt to analyze space-time dimensions of geosites bearing the traces of past lives with special concentration on our predecessors. With the application of network analysis, shortest route planning is obtained for sustainable tourist movement.
\end{abstract}

Key words: Location, cartography, nearest neighbour, network, sustainable

\section{INTRODUCTION}

Cemented deposits like pebble or cobble conglomerates in many places of Indian subcontinent bears the imprint of past lives of trees, animals and human being with their artifacts. Such fossils are useful for the classification and cataloguing of the entire roster of life with discernable evolution phases along with recognition of the divisions of geologic time (Dietz et al., 1987). Fossil forests have been found on all continents which are representative of early plant lives, even sometimes with traces and remnants of animals present in past geological ages (Császár et al., 2009). Fossils are considered as data sources on early human subsistence patterns as well as the animal species related to paleoenvironmental history. Numerous stone tools ranging from the Lower Paleolithic to Neolithic have been yielded from such sedimentary deposits in both surface and stratified contexts occur with the vertebrate fossils (Chauhan, 2008). With a scope of better interpretation of the people-resources relationship in different sub-phases of hunting

\footnotetext{
* Corresponding author
} 
gathering landuse from Pleistocene to recent, such geosites are subjected to geoconservation nourishing the concept of open-air museum. The existence of such geosites with geoarchaeological remains worldwide sustain the cultural-historical and geodidactic tourism (Pralong \& Reynard, 2005; Pralong, 2009).

The paleoenvironmental histories and visualization of past ecological pyramids are among the motivations that draw the geotourists to the fossil sites. The past environment while scientifically interpreted not only includes its physical and biological characteristics but also the social and cultural factors relating to the impact of man on environment (Badam, 2013). Geoarchaeological interests boost the natural history of the concerned area from geological and archaeological perspectives emphasising on the interaction between human and environment since pre-historic times (Rapidah et al., 2018). The restoration of geoarchaeological landscape helps to elucidate a part of geological history and can facilitate to build the cultural heritage and identity of a place (Iorgulescu et al., 2010). The study of geoarchaeological sites thus focuses on the history of landscapes inhabitated by our predecessors and utilize them for educative purposes, involving the local community by creating new jobs and opportunities in tourism sector (Vijulie et al., 2014). The open air museums that exhibit the relationships of our predecessors with the environment are the principal attraction of the geoarchaeosites (Comşa, 1987). Geotourism development in such geoarchaeosites may raise the fund for geoconservation as well as assure the involvement of the members of host community, who get benefitted economically from archaeotourism. The scientific interest, recreational and aesthetic significance, accessibility and level of exposure of the landscape for geotourists are among the crucial pull factors in this context (Bentivenga et al., 2017; Palladino et al., 2013).

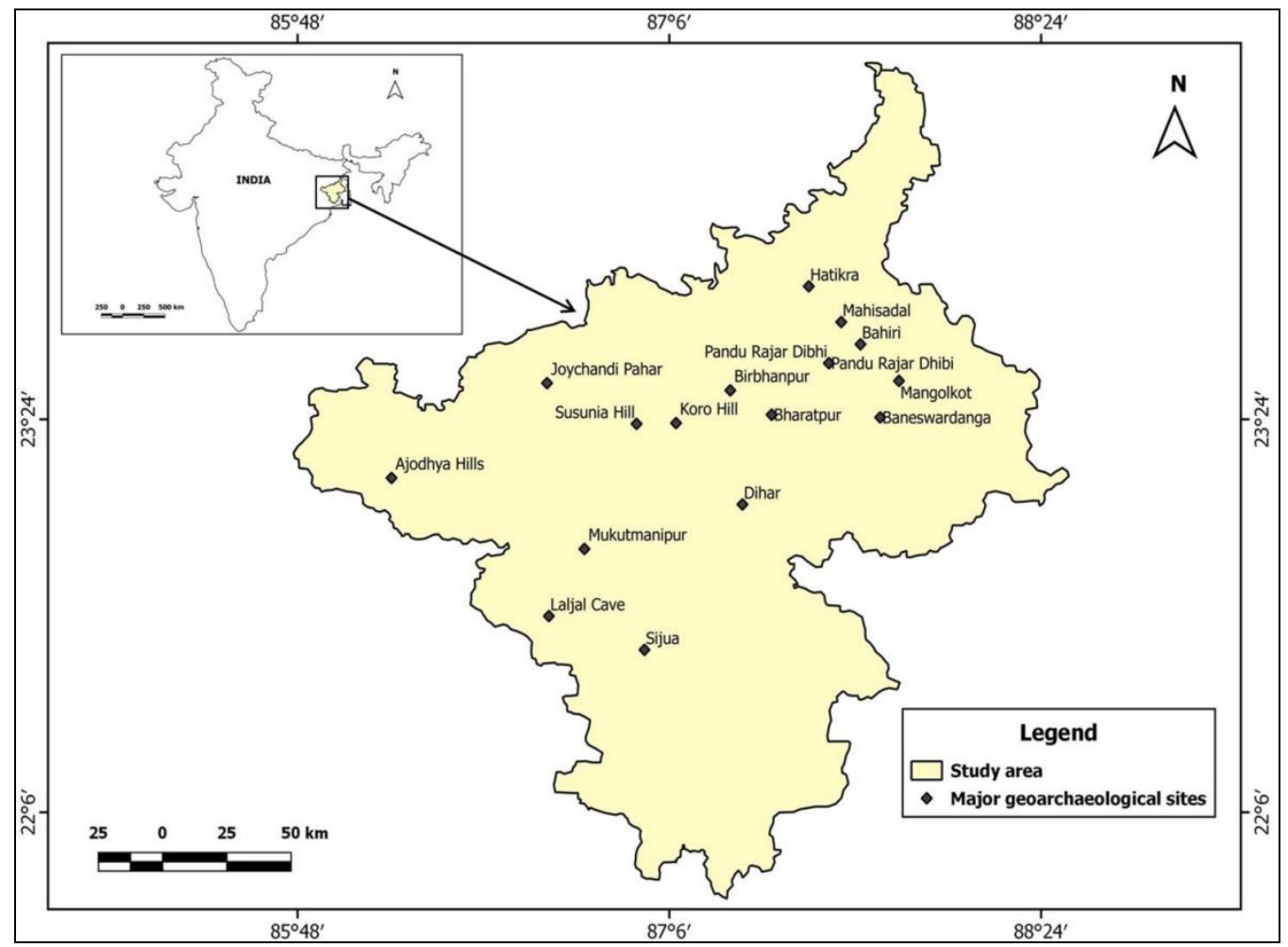

Figure 1. Location map of the study area with major geoarchaeosites 
Rarh ( $24^{\circ} 35^{\prime} \mathrm{N}$ to $21^{\circ} 47^{\prime} \mathrm{N}$ latitude and $85^{\circ} 49^{\prime} \mathrm{E}$ and $88^{\circ} 25^{\prime} \mathrm{E}$ longitude) is a geographical region, situated in the south-western part of West Bengal state of India (Figure 1), which comprises Birbhum, Paschim Bardhaman, Purba Bardhaman, Bankura, Purulia, Jhargram and Paschim Medinipur districts. It is endowed with continuity of geoarchaeological sites from Paleolithic to early historical.

The lateritic landscape of this region is not conducive for agriculture development and also not suitable for promoting any capital intensive industries, which required adequate water. However, this region has great potentially for tourism promotion because it consists of many hills, river valleys, caves, badland area etc which is yet to be promoted for geotourism (Chakrabarty \& Mandal, 2018).

The imprints of past civilizations underneath the soil discovered during last few decades manifest as a symbiosis between geomorphosites and geoarchaeosites in the context of geotourism. It may be promoted rather a form of educative tourism retaining the hidden recreational agenda that have been fulfilled simultaneously within its natural milieux. The study has been undertaken with the following objectives:

1. To identify and map the Paleolithic, Mesolithic, Neolithic and Chalcolithic sites of Rarh Bengal.

2. To analyse the nature of spatial distribution of these sites (Clustered, Random or Uniform) for designing geoarchaeotourism circuits.

3. To obtain the shortest path of the network from major urbanized transportation nodes of the region for suitability analysis on becoming accommodation and amenity hubs to cater geoarchaeotourists.

Geomorphosites of the study region are subjected to a more specialized investigation for geoarchaeotourism with a focus on the study of stratigraphic sequences. There are a number of river basins namely the Mayurakshi, Ajoy, Damodor, Dwarakeswar, Silabati, Kansabati and Subarnarekha constituted by rocks of various formations among which laterites are most conscipious.

The word Rarh has its origin in Sanskrit word roorha meaning rough and uneven, that is representative of the topography of the surface. The river basins in the region accommodate a number of hills, which are mostly typical monadnocks considered to be geotourism paradise. The scope of geoarchaeotourism further expands the horizon of tourism industry and contribute towards economic sustainabilities of the host population.

\section{MATERIALS AND METHODS}

As a multidisciplinary field of research, geoarchaeology uses the methods and techniques of earth sciences (Melelli et al., 2016). Geoarchaeological sites with abundance of archaeological vestiges ranging from Paleolithic stone tools to early historic artifacts of Rarh Bengal have been subjected to a qualitative research.

It involves prolonged engagement and persistent observation during field study with triangulation of available literary contributions and field collection exhibited by the archaeologists and geologists. Community interest level in the arena of conservation has been a subject of our study and the collection of Late Shyamsundar Sukul and his son Chandan Sukul (Figure 2) is very much noteworthy in this context.

Despite of institutional affiliations, they involved themselves in geoconservation and a few people like them assembled together to form a non-governmental research organization named Paschim Rarh Itihas O Sanskiti Charcha Kendra (Centre for history and culture of Rarh region) in the year 2001 for this purpose. Apart from hills like Ajodhya, Susunia, Laljal or Joychandi, there are a number of riverine sites of Rarh Bengal from where a huge number of artifacts have been discovered. In order to fulfill the first objective of chronological mapping of geoarchaeosites, GIS is opted. 


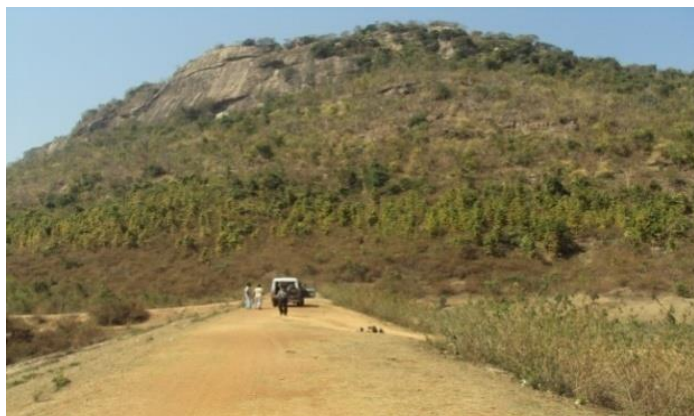

1. Ajodhya Hills

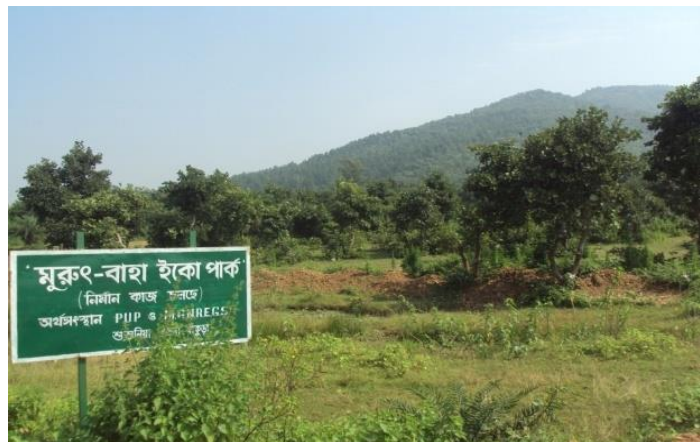

2. Susunia Hills

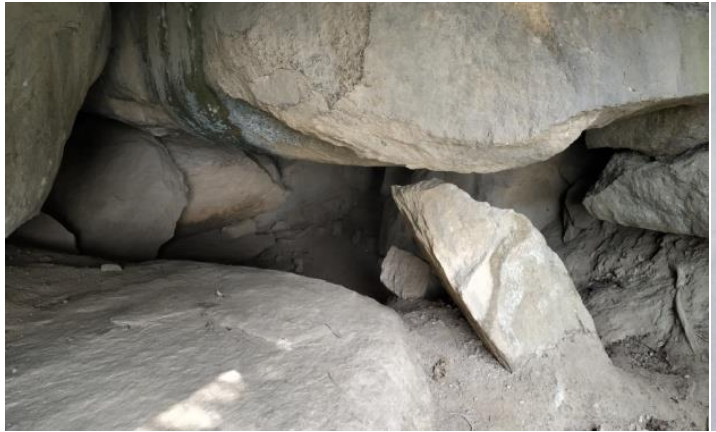

3. Laljal Cave

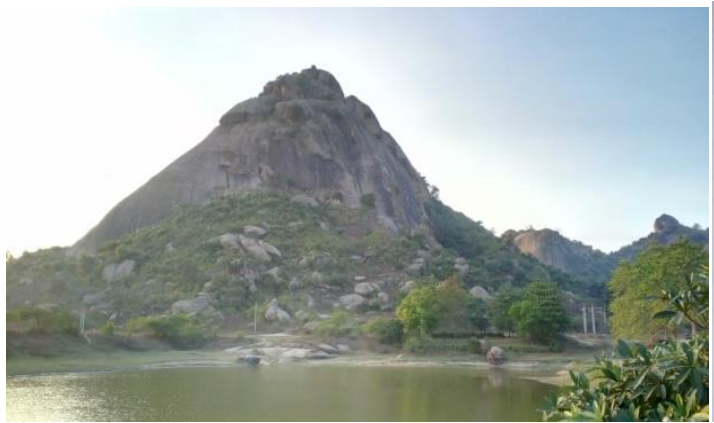

4. Joychandi Pahar

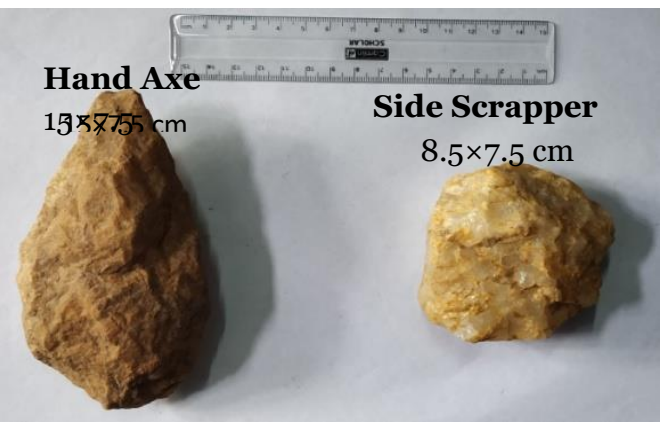

Artifacts

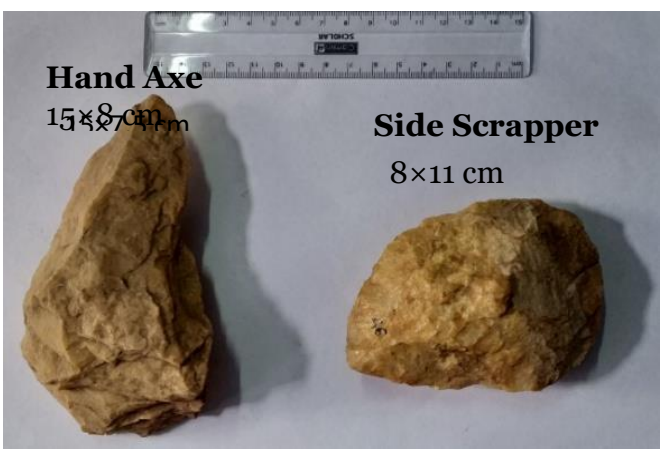

Artifacts

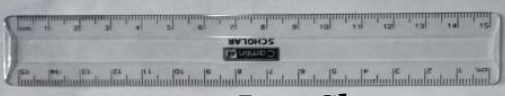

Iron Slags

$15 \times 8.5 \mathrm{~cm}$

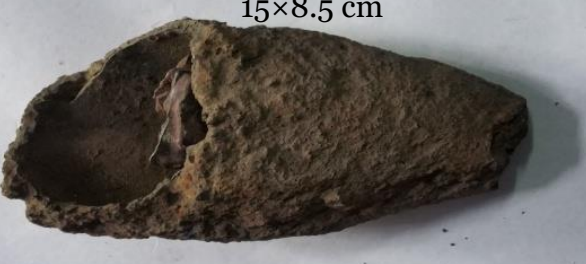

Artifacts
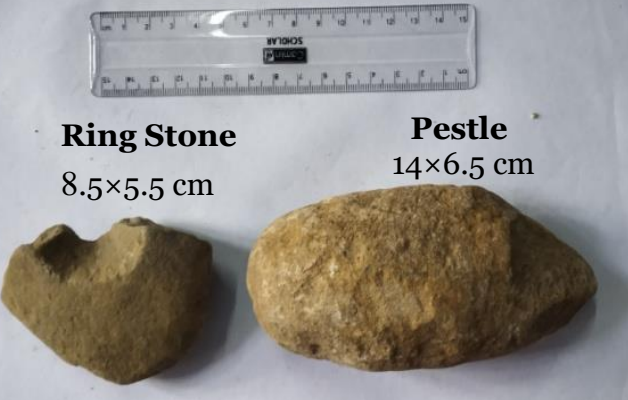

Artifacts

Figure 2. Hill sites as the treasure house of archaeological remains (Source: Photos from field and museum collections, 2018) 
Non spatial data on each of such geoarchaeosites have been integrated with spatial data in GIS domain for preparing geo-archaeo-tourist maps, which is nothing but the thematic map combining geological, geomorphological and archaeological aspects with basic tourist informations (Levratti et al., 2011). There has been use of QGIS 2.14 ESSEN for map making of Paleolithic, Mesolithic, Neolithic and Chalcolithic sites. Concerning each and every of such distributions, Nearest Neighbour Analysis (NNA) is applied to fulfill the objective to understand their distributional pattern, pre-requisite for a sustainable geotourism circuit planning. It is noteworthy to mention that the distance from an individual to its nearest neighbour, irrespective of direction is considered during analysis. In NNA, the ratio between observed mean distance and expected mean distance serves as the measure of departure from randomness (Clark \& Evans, 1954). To identify appropriate urban hubs offering adequate amenities for an appreciable geoarchaeotourism network, the Shortest Path Matrix is applied using the network analysis module of QGIS software. For satisfaction of tourists who want to visit all the sightseeing distinations but have only limited time as well as economic constraints, this particular module could be successfully applicable (Gill \& Bharath, 2013). It not only provides information and visual representation of the places of tourists interest but also determine the shortest and best route to travel the destinations depending on the value of impedances like time and travel cost. For planning and development of circuit tourism, GIS enabled network analysis has been used as tool to find out optimal routes connecting places of interest. The spatial database has been created in QGIS 2.14.22 Essen for network analysis along with spatial search operations for suitable urban amenitity hubs in order to cater the geotourists travelling Rarh Bengal.

\section{RESULTS AND DISCUSSIONS}

Geoarchaeotourism is a form of educative tourism that focuses on changing human adaptation with materialistic evidences. Apart from intrinsic values, geomorphosites possess economic, cultural, scientific and aesthetic values attracting visitors (Grey, 2004). Geoarchaeosites are none but the geomorphosites possessing cultural values associated with human ecology. The study region is endowed with a number of outstanding hills from where a number of artifacts have been discovered ( Table 1).

Table 1. Hill sites of Rarh Bengal bearing the imprints of early mankind

(Data source: Information and guidance obtained from Museums visited during field survey, 2018)

\begin{tabular}{|c|c|c|c|}
\hline Site & Type of Artefact & Age & Utility \\
\hline $\begin{array}{c}\text { Ajodhya Hills } \\
23^{\circ} 12^{\prime} \mathrm{N}, 86^{\circ} \mathrm{O} 7^{\prime} \mathrm{E}\end{array}$ & $\begin{array}{c}\text { Hand Axe } \\
\text { Side Scrapper }\end{array}$ & $\begin{array}{c}\text { Palaeolithic and } \\
\text { Mesolithic }\end{array}$ & $\begin{array}{c}\text { Hunting and dressing } \\
\text { of animal meat }\end{array}$ \\
\hline $\begin{array}{c}\text { Susunia Hills } \\
23^{\circ} 23^{\prime} \mathrm{N}, 86^{\circ} 59^{\prime} \mathrm{E}\end{array}$ & $\begin{array}{c}\text { Hand Axe } \\
\text { Side Scrapper }\end{array}$ & Palaeolithic & $\begin{array}{c}\text { Hunting, dressing and } \\
\text { processing meat }\end{array}$ \\
\hline $\begin{array}{c}\text { Laljal Hill and Cave } \\
22^{\circ} 44^{\prime} \mathrm{N}, 86^{\circ} 40^{\prime} \mathrm{E}\end{array}$ & Iron Slags & Chalcolithic - Iron & Molding \\
\hline $\begin{array}{c}\text { Joychandi Pahar } \\
23^{\circ} 31^{\prime} \mathrm{N}, 86^{\circ} 4 \mathrm{O}^{\prime} \mathrm{E}\end{array}$ & $\begin{array}{c}\text { Ring Stone } \\
\text { Pestle }\end{array}$ & Neolithic & Agriculture \\
\hline
\end{tabular}

Among the hills (Table 1), Ajodhya hill complex characterized by subdued pediment is very extensive with dominance of granitic and gneissic rocks. The alignment of the range resembles to English word L, which acts as a watershed between two river basins, namely Kasai and Subarnarekha. Gorgaburu $(677 \mathrm{~m})$, the height peak of this hill complex, is the vantage point for the geographical region.

The microliths are found at the base of Ajodhya hills within accumulated hill-wash materials. This is why the colluvial sites of Ajodhya hill complex attract the professonal 
archaeologists (Basak et al., 2015). The Susunia hill situated in the north-east of Chhatna, Bankura district is another geosites with enormous geoarchaeological significance. The geo-physical appearances of Susunia $(437 \mathrm{~m})$ is quite similar to world famous Mt. Monadonack (965 m) of USA (Sinha, 2016). It is one of the renowned geo-archaeosites of Bankura district, famous for discovery of Stone Age tools considerded to be the evidence of high level development of Acheulian technology (Sen et al., 1963).

Table 2. River basin sites of Rarh Bengal bearing the imprints of early mankind

(Data source: Literatute review and field study, 2018)

\begin{tabular}{|c|c|}
\hline Sites & \begin{tabular}{|l} 
Geoarchaeological heritages \\
\end{tabular} \\
\hline $\begin{array}{l}\text { Pandu rajar Dibhi } \\
\left(23^{\circ} 35^{\prime} \mathrm{N} ; 87^{\circ} 39^{\prime} \mathrm{E}\right)\end{array}$ & $\begin{array}{l}\text { Excavated in various phases since } 1954 \text { at the village Panduk on the southern } \\
\text { bank of river Ajay varied stone tools (microliths), animal skeletal remains, } \\
\text { human burials, copper and even iron implements representing continuity of } \\
\text { civilization along with painted potteries (Dasgupta, 1967) have been discovered. }\end{array}$ \\
\hline $\begin{array}{l}\text { Mangalkot } \\
\left(23^{\circ} 32^{\prime} \mathrm{N} ; 87^{\circ} 54^{\prime} \mathrm{E}\right)\end{array}$ & $\begin{array}{l}\text { Excavation reveals six phases of Black and red ware culture from the old alluvium } \\
\text { at the right bank of Kunur river, a tributary of the river Ajay (Ray \& Mukherjee, 1992). }\end{array}$ \\
\hline $\begin{array}{l}\text { Dihar } \\
23^{\circ} \mathrm{O} 7^{\prime} \mathrm{N}, 87^{\circ} 21^{\prime} \mathrm{E}\end{array}$ & $\begin{array}{l}\text { Numerous microlith have been discovered from the older alluvium tract on } \\
\text { the bank of river Dwarakeswar. }\end{array}$ \\
\hline $\begin{array}{l}\text { Hatikra } \\
\left(23^{\circ} 50^{\prime} \mathrm{N} ; 87^{\circ} 35^{\prime} \mathrm{E}\right)\end{array}$ & $\begin{array}{l}\text { Situated on the right bank of Bakreswar river in Birbhum district, this site } \\
\text { characteristically represents the evidence of two subsequent cultural } \\
\text { phases, namely Chalcolithic and Iron Age. The bone remains of domestic } \\
\text { animals, black-and-red ware, plain and painted pottery, mud floors, reed } \\
\text { huts with mud plaster, pounders, stone mullers, sharpners, semi - precious } \\
\text { stones etc have been discovered from this excavated Black-and-Red ware } \\
\text { sites (Nandy and Pal, 2014). }\end{array}$ \\
\hline $\begin{array}{l}\text { Birbhanpur } \\
\left(23^{\circ} 29^{\prime} \mathrm{N}, 87^{\circ} 18^{\prime} \mathrm{E}\right)\end{array}$ & $\begin{array}{l}\text { Situated on the right bank of the Damodar near Durgapur, this was once a } \\
\text { place for manufacturing microliths (Lal, 1958). Quartz, quarzite, basalt, } \\
\text { rock crystals, fossil wood were among the raw material used as evident from } \\
\text { the microlith discovered. }\end{array}$ \\
\hline $\begin{array}{l}\text { Mahisdal } \\
\left(23^{\circ} 43^{\prime} \mathrm{N} ; 87^{\circ} 42^{\prime} \mathrm{E}\right)\end{array}$ & $\begin{array}{l}\text { The area was home of our early age predecessors of the past stone ages } \\
\text { (Chakraborty, 2007). This site situated on the bank of river Kopai near } \\
\text { Santiniketan bears Chalcolithic and Iron age evidences consisting of } \\
\text { microlithic tools, copper and iron tools. }\end{array}$ \\
\hline $\begin{array}{l}\text { Bharatpur } \\
\left(23^{\circ} 24^{\prime} ; 87^{\circ} 27^{\prime}\right)\end{array}$ & $\begin{array}{l}\text { Situated on the left bank of Damodar near Panagarh, this site is famous for } \\
\text { a brick made Buddhist stupa in the upper most layer followed by Neolithic } \\
\text { and Chalcolithic evidences in the substratums. }\end{array}$ \\
\hline $\begin{array}{l}\text { Gopiballabpur } \\
22^{\circ} 12^{\prime} \mathrm{N}, 86^{\circ} 53^{\prime} \mathrm{E}\end{array}$ & $\begin{array}{l}\text { A number of pebble tools have been discovered in laterites from the bank of } \\
\text { river Subarnarekha (Dasgupta, 2007) }\end{array}$ \\
\hline $\begin{array}{l}\text { Sijua } \\
\left(22^{\circ} 38^{\prime} \mathrm{N}, 87^{\circ} 00^{\prime} \mathrm{E}\right)\end{array}$ & $\begin{array}{l}\text { In the older alluvial terrace named Sijua formation developed in Kansabati } \\
\text { basin, numerous mammalian fossil bones, human skeletal fossils of early } \\
\text { Holocene (10ooo years B.P. approximately) and microlithic objects have } \\
\text { been discovered. (Ghosh \& Majumder, 1981) }\end{array}$ \\
\hline $\begin{array}{l}\text { Mukutmanipur } \\
\left(22^{\circ} 57^{\prime} \mathrm{N}, 86^{\circ} 47^{\prime} \mathrm{E}\right)\end{array}$ & $\begin{array}{l}\text { At the Kansabati-Kumari interfluves, Mukutmanipur is a famous } \\
\text { recreational tourism site with its dam and reservoir. Most of the evidences } \\
\text { of early civilization have been submerged under water of the reservoir } \\
\text { except a few Paleolithic and Mesolithic evidences survived in the rocky } \\
\text { islands within it. At Tulsipur area nearby, the discovery of the evidences on } \\
\text { overlap between copper and iron age is noteworthy (Dasgupta, 1981). }\end{array}$ \\
\hline $\begin{array}{l}\text { Tarafeni reservior } \\
\text { bridge } \\
\left(22^{\circ} 40^{\prime} \mathrm{N}, 86^{\circ} 47^{\prime} \mathrm{E}\right)\end{array}$ & $\begin{array}{l}\text { Tarafeni is a tributary of Kansabati river. Paleolithic and Mesolithic tools } \\
\text { have been discovered while constructing the reservoir bridge, which is a } \\
\text { popular tourist destination of the region. }\end{array}$ \\
\hline
\end{tabular}

Vertebrate fossils of Lion, Spotted Hyaena, Leopard, Horse, Giraffe, Indian buffalo, Spotted deer, Siwalic elephant (already extinct), Indian bison, Nilgai, Barking deer etc 
have also been discovered from this bornhardt-type residual hill made of quartzites (Nandy \& Pal, 2014) Laljal is another hill site comparatively of smaller dimensions formed by granite and gneiss rocks. It is famous for its caves located mostly on its south facing slopes, once the habitation of our predecessors in early age bearing the traces cave painting of Mesolithic and Neolithic era. This is however a place of extensive physical weathering that challenges the in situ conservation of the geoarchaeosite (Bhowmick, 1992). Joychandi on the other hand is a peculiar hill formed of a single massive igneous rock as representative of volcanic eruption in the past geological period.

The steep freeface of Joychandi hill attracts the rock climbers from different parts of the world and it is a famous place for the training of rock climbing in Rarh Bengal. This place was also inhabitated by the early settlers and therefore significant from geoarchaeological point of view. The following are the major riverine geotourism sites (Table 2) with enormous geotourism potentials. In order to investigate the nature of distribution of such geoarchaeosites Nearest Neighbour Analysis (NNA) is adopted. It is actually a method developed by Plant Biologist Clark and Evans in the year 1954 by ratioing mean observed and mean expected distances of the objects concerned. Nearest Neighbour Index (NNI) is computed by using following formula:
$\mathrm{NNI}=\mathrm{do} / \mathrm{de} \quad$ and $\quad \mathrm{de}=\frac{1}{\sqrt[2]{\text { N/A }}}$
Where,
do $=$ mean observed distance of nearest neighbor settlements,
de $=$ mean expected distance of settlements,
$\mathrm{N}=$ total number of settlements,
$\mathrm{A}=$ total area of the concerned region.

The result ranges between o (clustered pattern) and 2.15 (uniform/regular pattern) representing various categories of distributional status as manifested in table 3 for the geoarchaeosites of Rarh Bengal. When the computed value is 1.0, the nature of distribution is interpretated as random. If the distribution of geoarchaeosites are found clustered, it appears readily conducive for promoting circuit tourism.

The NNA values computed (Table 3) for Paleolithic, Mesolithic, Neolithic and Chalcolithic sites suggest that experimenting on geoarchaeotourism in the region may begin with marketing the Paleolithic sites at the initial phase of development. The success of this venture may exert snowball effects in the promotion of circuit tourism based on Mesolithic, Neolithic and Chalcolithic sites in near future.

Table 3. Nearest Neighbour Analysis of geoarchaeological sites in Rarh Bengal

\begin{tabular}{|c|l|c|c|}
\hline $\begin{array}{c}\text { Sites } \\
\text { Category }\end{array}$ & \multicolumn{1}{|c|}{ Name of the Major sites } & NNI & $\begin{array}{c}\text { Distributional } \\
\text { status }\end{array}$ \\
\hline $\begin{array}{c}\text { Palaeolitic } \\
\text { sites }\end{array}$ & $\begin{array}{l}\text { Susunia hill and surrounding area, Guniada hill, } \\
\text { Ganganir Math, Mukutmanipur, Kankradara, } \\
\text { Hatikheda, Kana Pahar, Hanumatha Tarafeni river } \\
\text { bridge, Gopiballabpur, Chhatinasole, Rangamatia. }\end{array}$ & 0.85 & $\begin{array}{c}\text { More Random } \\
\text { than Clustered }\end{array}$ \\
\hline $\begin{array}{c}\text { Mesolithic } \\
\text { sites }\end{array}$ & $\begin{array}{l}\text { Khowai, Birbhanpur, Koro hill, Susunia hill and } \\
\text { surrounding area, Ganganir Math, Mukutmanipur, } \\
\text { Ajodhya hills, Kana Pahar, Tilabani, Kuilapal Tarafeni } \\
\text { river bridge, Gagra, Jambani. }\end{array}$ & 1.07 & $\begin{array}{c}\text { More Random } \\
\text { than Regular }\end{array}$ \\
\hline $\begin{array}{c}\text { Neolithic } \\
\text { sites }\end{array}$ & $\begin{array}{l}\text { Pandu Rajar Dhibi, Bharatpur, Susunia hill and } \\
\text { surrounding area, Laljal cave. }\end{array}$ & 1.88 & $\begin{array}{c}\text { More Regular } \\
\text { than Random }\end{array}$ \\
\hline $\begin{array}{c}\text { Chalcolithic } \\
\text { sites }\end{array}$ & $\begin{array}{l}\text { Hatikra, Mahisadal, Pandu Rajar Dhibi, Mangolkot, } \\
\text { Bahiri, Baneswardanga, Bharatpur, Dihor, Sijua. }\end{array}$ & 1.23 & $\begin{array}{c}\text { More Random } \\
\text { Than Regular }\end{array}$ \\
\hline
\end{tabular}


For spatial database management in geotourism, a basin oriented mapping is prescribed with extensive use of GIS (Chakrabarty \& Mandal, 2018). Decision making enhanced by GIS technology provides a tool box of technique to deal with the spatial database useful for sustainable tourism promotion (Efflong et al., 2013).

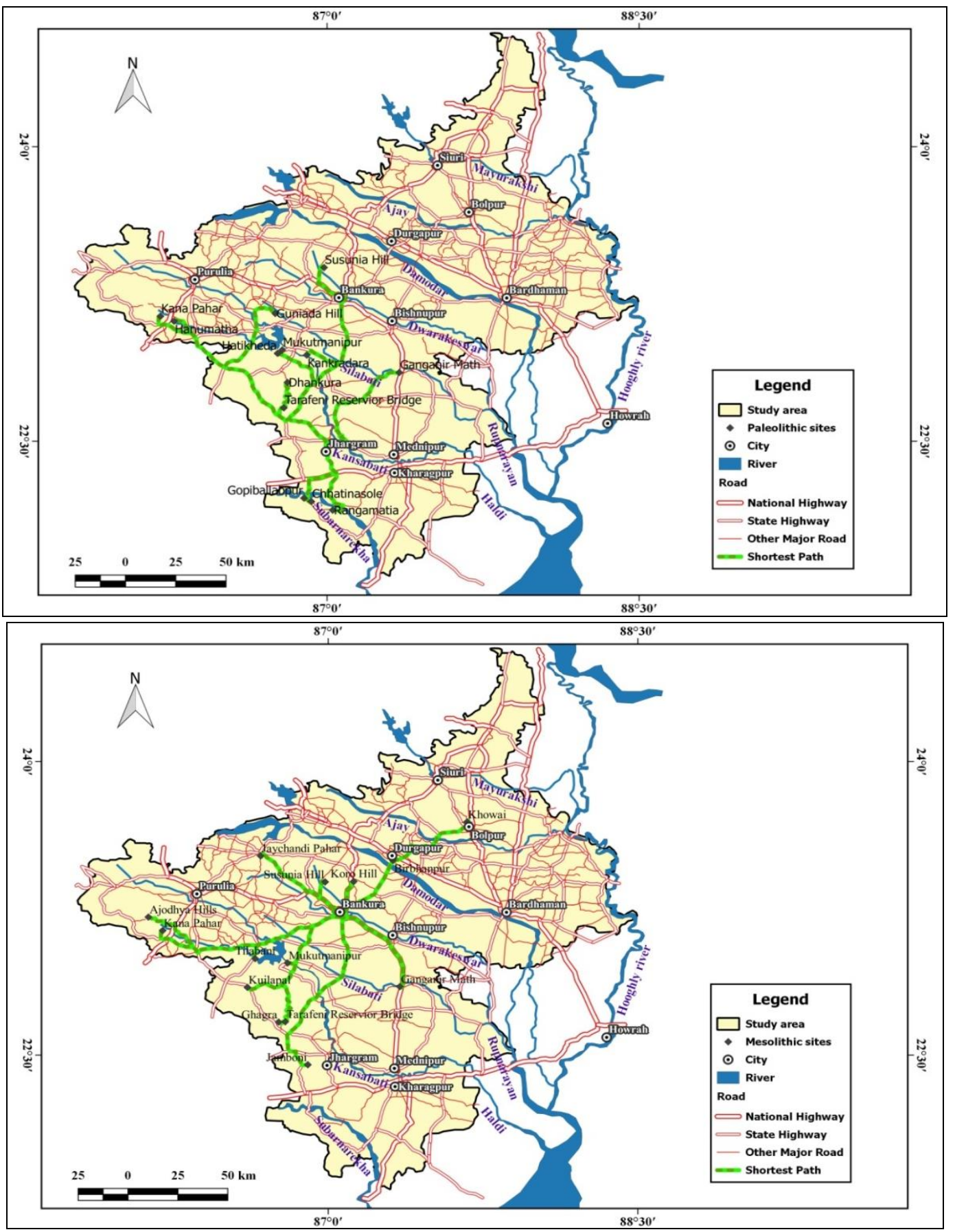


Geoarchaeosites for Geotourism: A Spatial Analysis for Rarh Bengal in India
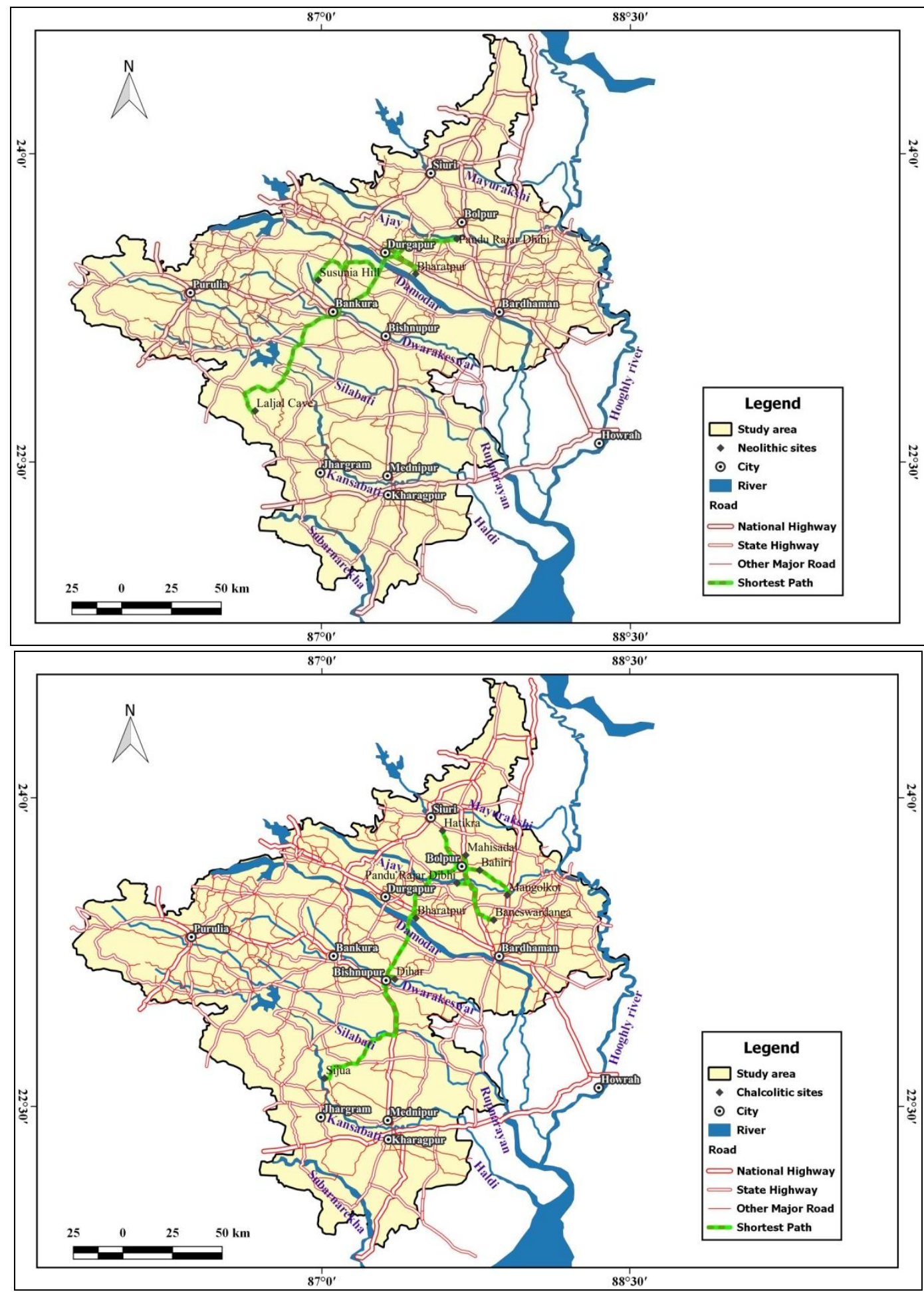

Figure 3. Shortest path operation for Paleolithic, Mesolithic, Neolithic and Chalcolithic Sites 
The urge to complete sightseeing in a limited time period available leads to determine the optimum path for the movement of visitors. This arises the scope of using network analysis to facilitate decision making in this context. Considering the geoarchaeosites as the network analysis objects, the network dataset of the region has been taken under GIS design and applications. As four categories of geoarchaeosites are available in the region for visit, four network layers have been developed for convenience of analysis in the network window. Figure 3 represents Shortest path map of each site categories to facilitate visitors interested in specific (e.g. Paleolithic/Mesolithic/Neolithic/ Chalcolithic) attractions. With such enormous resources base, there arises the scope of developing another type of circuit tourism. Scope of selection of destinations among the circuits by individual tourist is vital in this context because it bears intimate relationship with the availability of leisure time for travel and economic constraints.

In stead of specific geoarchaeosite categories such circuits possess representative of various categories together in its fold to serve the educative purposes of geotourism. Such ventures involve both host and guest, who may not have enough technical background to discreminate between the significance of Paleolithic, Mesolithic, Neolithic or Chalcolithic sites but have interest in geoarchaeology while travelling as geotourists.

To cater them, various amenities are essential, which are usually unavailable in excavation sites. This is why a number of base settlement (Table 4) have been selected through search operation using the software in order to strengthen the viability of circuit tourism. The carrying capacity issues could not arise for most of the excavation sites because the visitors would be accommodated in the urban hubs, namely Bolpur, Bankura, Purulia, Mukutmanipur and Jhargram.

Table 4. Viability of circuit tourism

\begin{tabular}{|c|c|l|}
\hline $\begin{array}{c}\text { Geoarchaeotourism } \\
\text { circuits proposed }\end{array}$ & $\begin{array}{c}\text { Base settlement (Urban } \\
\text { facility hubs) }\end{array}$ & \multicolumn{1}{|c|}{ Merit of the hub } \\
\hline Circuit 1 & Bolpur & A very developed tourist town \\
\hline Circuit 2 & Bankura & District headquarter \\
\hline Circuit 3 & Purulia & District headquarter \\
\hline Circuit 4 & Mukutmanipur & A well known ecotourism centre \\
\hline Circuit 5 & Jhargram & District headquarter \\
\hline
\end{tabular}

Figure 4 represents the tour plan for geoarchaeotourism sites in the region. There is entry and exit point for international tourists at Kolkata, the city of joy, a world famous metropolis with international airport. Geotourists either have to drive from Kolkata airport about $160 \mathrm{~km}$ to reach Bolpur, one of the amenity hubs of Rarh Bengal or may also prefer a train journey from Howrah station, which is about $20 \mathrm{~km}$ from Kolkata airport. A tourist willing to visit all the circuits together may spent first night at Bolpur, second night at Bankura, third night at Purulia, fourth night at Mukutmanipur and fifth night at Jhargram, from where may finally depart by rail for Howrah to avail the route of returning to their places of origin.

\section{CONCLUSIONS}

Archaeologists are end user of excavated materials, which were found embedded in rock surface. Primarily most of these tangible heritages are geological legacy, thereby termed as geoarchaeological which offers outstanding scientific, aesthetic, cultural historical and recreational values (Rapidah et al, 2018). With the incorporation of geoarchaeosites for geotourism, visitors could be enlighted on changing environm ent of different geological ages. It is not until the of spatio-temporal database management under GIS domain, the spectators of open-air museum could relate the exhibits with the 
time frame of evolution. Depending on archaeological time scale based mapping of the geoarchaeosites for the study area, a number of geoarchaeotourism circuits could be developed in which each site may serve as an open air museum.

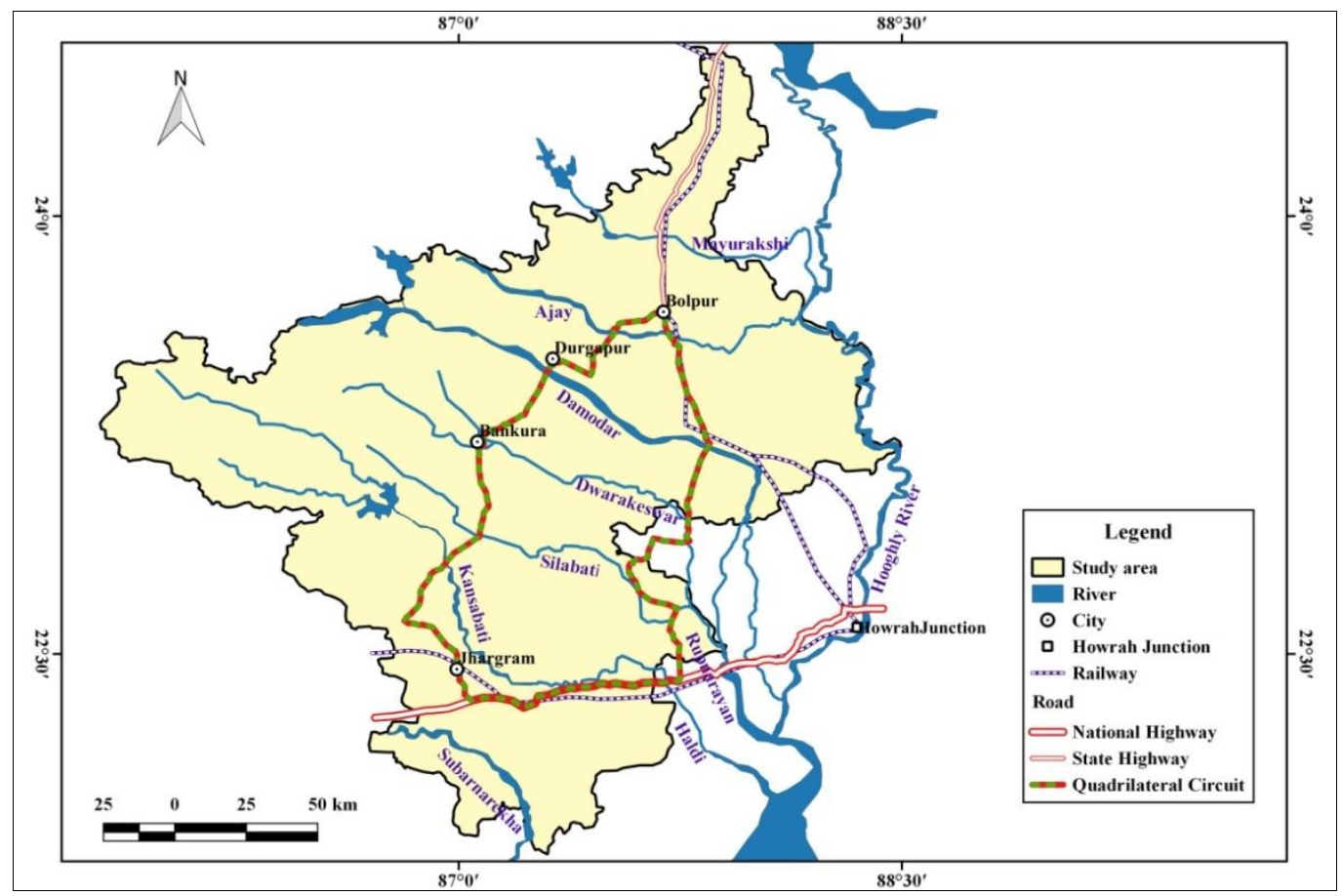

Figure 4. Geoarchaeotourism circuits of Rarh Bengal

A spatial analysis undertaken with the application of nearest neibour and network analyst extension of GIS software reveals the pattern of distribution of such geoarchaeosites for planning and development of geotourism in the region. The expectation is to increase the volume of quality visitors for whom educative tourism is an essential requirement. Trained guides are required to explain the past geological environment relating with the geoarchaeological materials excavated from these sites. The audio-visual infrastructure in interpretation centre of each of such sites is essential to draw the attention of geotourists, which serves the objective of blending geomorphosites with the cultural history of mankind.

\section{Acknowlegments}

The authors would like to express their gratitude to Sri Goutam De, one of the founders of Paschim Rarh Itihas O Sanskiti Charcha Kendra (Centre for history and culture of Rarh region) and Sri Chandan Sukul, one of the active members of this research organization for extending their active support.

\section{REFERENCES}

Badam, G., L. (2013). An integrated approach to the Quaternary fauna of South And South East Asia - a summary. Journal of the Palaeontological Society of India, 58(1), p-102.

Basak, B., Paul, A., \& Dasgupta, S. (2015). Geoarchaeological Investigations in the Ayodhya Hills, Purulia District, West Bengal-new paths and future Directions. Pratna Samiksha A Journal of Archaeology, New series, Vol. 6, P. 1-5. 
Bentivenga, M., Palladino, G., Prosser, G., Guglielmi, P., Geremia, F., \& Laviano, A. (2017). A Geological Itinerary Through the Southern Apennine Thrust Belt (Basilicata-Southern Italy). Geoheritage, 9 (1), p. 1-17.

Bhowmick, A., C. (1992). On the conservation of bone, shell and iron objects of Laljal and bhaluksonda Cave, Pratna Samiksha, Vol.1, p. 197-200.

Chakrabarty, P., \& Mandal, R. (2018). Geotourism mapping for sustainability: A basin oriented approach. GeoJournal of Tourism and Geosites, vol. 21, no. 1, p.174-185.

Chakrabarty, P., \& Mandal, T. (2018). Tourism and sustainability: a geographical study in Rarh region of West Bengal. In: Shukla, P., Shukla, P., Chakraborty, P. \& Dey, N. (Eds), Sustainable development a dynamic perspective, Anjan Publisher, Kolkata, p. 193-202.

Chakraborty, S., C. (2007). Archaeological heritage of the tract around Santiniketan area. In: Ray, R. (Eds). Fragile environment of Santiniketan: Unwanted development in the land of Khoai, Nagarik Mancha Publisher, Kolkata, p. 89-101.

Chauhan, P., R. (2008). Large mammal fossil occurrences and associated archaeological evidence in Pleistocene contexts of peninsular India and Sri Lanka. Quaternary International, 192, p. 32, Elsevier Ltd and INQUA.

Clark, P.J., \& Evans, F.C. (1954), Distance to nearest neighbor as a measure of spatialrelationships in populations. Ecology, 35 (4), p. 445-453.

Comşa, E. (1987). Neolithic in Romania - Considerations. Academy Socialist Republic of Romania, Bucharest, p. 199.

Császár, G., Kázmér, M., Erdei, B., \& Magyar, I. (2009). A possible Late Miocene fossil forest PaleoPark in Hungary. Notebooks on Geology - Book 2009/o3 (CG2009_Bo3), Chapter 11, p. 121-133.

Dasgupta, P.C (1967). Pragoitihasik Susunia (in Bengali). Calcutta.

Dasgupta, P.C. (1981). Pragaitihasik Bangla. Anima Prakashani, Kolkata, p. 102.

Dasgupta, P.C. (2007). Subarnarekhar prangane aranyakanya Kansabati. Anima Prakashani, Kolkata, p. $26-32$.

Dietz, R.S., Péwé, T.L., \& Woodhouse, M. (1987). Petrified wood (Araucarioxylon Arizonicum): proposed as Arizona's state fossil. Arizona-Nevada Academy of Science, No. 2, Vol. 22, p. 110.

Efflong, E., Iyiola, F., Ibe, P., Alagbe, A., \& Liwah, N. (2013). Inventory of tourism in Cross River State, Nigeria, using Geographical Information System (GIS). FIG Working Week 2013 Environment for Sustainability, Nigeria, p.1-14.

Ghosh, R., N., \& Majumder, S. (1981). Neogene-Quaternary sequence of Kasai Basin, West Bengal, India, Proc. Field Conf Neogene-Quaternary Boundary, India, 1979, (Eds.) Sastri et al., Geological Survey of India, p. 63-73.

Gill, N., \& Bharath, B.D. (2013). Identification of optimum path for tourist places using GIS based network analysis: a case study of New Delhi. International Journal of Advancement in Remote Sensing, GIS and Geography, Vol.1, No.2, P. 34-38.

Grey, M. (2004). Geodiversity valuing and conserving abiotic nature. John Wiley \& Sons Ltd, Chichester, p. 1-411.

Iorgulescu, F., Alexandru, F., Creţan, C.G., Kagitci, M., \& Iacob, M. (2010). Considerations regarding the valuation and valorification of cultural heritage. Theoretical and Applied Economics, Vol. XVIII, No. 12 (565), p. 13-32.

Lal, B., B. (1958). Birbhanpur, A Microlithic Site In the Damodar Valley, West Bengal, Ancient India, No. 14, p. $1-48$.

Levratti, S., Rodrigues, M., L., Castaldini, D., \& Levi. S., T. (2011). Study of the geomorphological and archaeological aspects of sintra area (Portugal) as contribution to its tourist appraisal and promotion. GeoJournal of Tourism and Geosites, no.2, vol. 8, p. 227-239

Melelli, L., Bizzarri, R., Baldanza, A., \& Gregori, L. (2016). The Etruscan "Volumni Hypogeum" archeo-geosite: New sedimentological and geomorphological insights on the Tombal Complex. Geoheritage, 8, p. $301-314$.

Nandy. S., \& Pal, T., K. (2014). Animal remains from South-Western part of West Bengal, India and their relevance to the ancient civilization of the area. Zoological Survey of India, Kolkata, No. 337, P. 1-171.

Palladino, G., Prosser, G., \& Bentivenga, M. (2013). The Geological Itinerary of Sasso di Castalda: A Journey into the Geological History of the Southern Apennine Thrust-belt (Basilicata, Southern Italy). Geoheritage, 5 (1), p. 47-58.

Pralong, J.P., \& Reynard, E. (2005). A proposal for the classification of geomorphological sites depending on their tourist value. Il Quaternario, 18 (1), p. 315-321.

Pralong, J.P. (2009). Targed groups and geodidactic tools: to need to adapt tourist offer and demand. Mem. Descr. Carta Geol. d'It. LXXXVII, p. 145-152.

Rapidah, M.S., Mohamed, K.R., Ali, C.A., Leman, M.S., \& Saidin, M. (2018). A geotouristic itinerary: a proposal for geotourism and archaeotourism development of Lenggong valley, Perak, Malaysia. GeoJournal of Tourism and Geosites, vol. 22, no. 2, p. 597-624.

Ray, A., \& Mukherjee, S., K. (1992) Excavation at Mangalkot. Pratna Samiksha, Vol. 1. P. 107-134.

Sen, D., Ghosh, A.K., \& Chatterjee, M. (1963). Palaeolithic Industry of Bankura. Man in India 43(2), p. $100-113$.

Sinha, M. (2016). Gandeshwari rivulet: A geomorphic study, West Bengal, India. Social Science Review, Vol. 2, No.2, p.78.

Vijulie, I., Matei, E., Tîrlă, L., Manea, G., \& Zorzoliu, T. (2014). The role of archaeological landscape restoration in building the local tourism image: the Gumelniţa archaeo - park (Drăgăneşti - Olt, Romania). GeoJournal of Tourism and Geosites, vol. 13, no. 1, p.52-65.

Submitted:

20.03.2019
Revised:

03.06.2019
Accepted and published online 25.06.2019 